\title{
Development of Standard Approach for Sickle Blade Manufacturing
}

\author{
M. N. A. Noordin", R. M. Hudzari", H. N. Azuan", M. S. Zainon ${ }^{*}$, S. B. Mohamed", S. A. Wafi ${ }^{*}$ \\ *Faculty of Innovative Design and Technology, Universiti Sultan Zainal Abidin, Gong Badak, Terengganu, 21300, Malaysia \\ E-mail:noordin.frit@gmail.com \\ ${ }^{\#}$ Faculty of Bioresources and Food Industry, Universiti Sultan Zainal Abidin, Tembila, Terengganu,22000 Besut, Malaysia \\ E-mail:mohdhudzari@unisza.edu.my,nurazuanhusin@gmail.com
}

\begin{abstract}
The sickle blade used in the motorized palm cutter known as "CANTAS" provides fast, easy and safe pruning and harvesting for those hard to reach applications. Jariz Technologies Company is experiencing a problem in the consistency of sickle blade which was supplied by various blade manufacturers. Identifying the proper blade material with a certain hardness value would produce a consistent as well as a long lasting sickle blade. A Standard Operating Procedure (SOP) in the manufacturing of the sickle blades was suggested to ensure a consistent blade. From this study, the optimum temperature for hardening and tempering of SUP 9 had been identified as $850{ }^{\circ} \mathrm{C}$ for hardening and $480{ }^{\circ} \mathrm{C}$ for tempering. The final hardness after heat treatment for SUP 9 was around 55HRC.
\end{abstract}

Keywords - sickle blade, CANTAS, palm cutter, manufacturing standard.

\section{INTRODUCTION}

This research was part of the Ministry of Education (MoE) new initiative called as Public-Private Research Network (PPRN). PPRN is a model of strategic cooperation between universities, industries and government agencies to promote innovation programs based demand and to increase productivity and strengthen economic development through commercialization. The main objective is to create a knowledge-friendly ecosystem where knowledge and expertise from the universities are disseminated to the industries and small-medium-sized enterprises (SME). It is expected will benefit the knowledge user of industry, which is to be connected to the knowledge producer of higher education and research institutions to solve their technology problems.

Jariz Technologies Sdn Bhd is one of the local companies selected under PPRN program. It was established on 4th April 2003. It is a full service factory automation system design and development firm providing responsive, cost effective, robust factory automation system/solution on the factory floor with total technical support to end-users. Their main products are consultation, machine automation, trading and oil palm tools mechanization. One of their products is motorized palm harvester known as "CANTAS" [1] (Fig. 1). It consists of three main components. The first component is a "sickle blade" specially designed tool used for harvesting oil palm fresh fruit bunches (FFB) and pruning fronds. The second component is a "head", which are pounded with rapid acceleration gear along with optimized transmission for best cutter performance and the third component is a "drive shaft" system provides superior gear surface contact area for maximum power transfer and cutting performance.

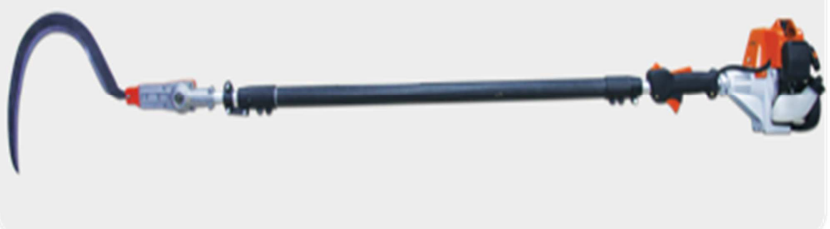

Fig. 1 CANTAS Advance II motorized cutter

Advantages of CANTAS include:

- CANTAS Advance II motorized cutter provides fast, easy and safe pruning and harvesting for those hardto-reach applications.

- The light-weight design and comfortable controls ensure maximum operator comfort.

- Telescoping shaft and optional tensions provide added reach for cutting flexibility.

- CANTAS motorized cutter delivers commercial-grade performance and optimum oil palm tree care versatility.

The company is currently experiencing a problem in the consistency of sickle blade which were supplied by various 
blade manufacturers. The sickle that manufactured by the supplier does not follow the standard geometric design required by Jariz Technologies Sdn Bhd. The sickle is sometimes unsafe and dangerous to those who uses the CANTAS because of the brittle blade and easily fractured. Identifying the proper blade material with a certain hardness value would produce a consistent as well as long lasting sickle blade [2]. This involves obtaining samples from a few blade suppliers. Site visits to the blade manufactures identified the method and procedures used in manufacturing the blades.

\section{MATERIAL AND METHOD}

The first part deals with analyzing the current blade, where and how it is being manufactured and identifying if any standard operating procedures are being observed. The blades are then analyzed to determine the material and hardness. The sharpness of the blade is also being measured using a Rockwell Hardness tester. From this data, we derive the endurance of the blades. Finally, we would produce a Standard Operating Procedure (SOP) in the manufacturing of the sickle blades and hence obtain a consistent blade [3][7].

The performance of the blade depends on various parameters. The major parameters affecting the performance of the blade are the type of material, hardness, sharpness and geometry. However, this project will study the material type and hardness plus the procedures in manufacturing the blades thus ensuring a consistent sharpness and endurance of the blades.

The performance of the blade depends on various Parameters. The major parameters affecting the performance of the blade are the type of material, hardness, sharpness and geometry. However, this project will study the material type and hardness plus the procedures in manufacturing the blades thus ensuring a consistent sharpness and endurance of the blade.

Steel can be treated with intense heat to give it different properties of hardness depending on the amount of carbon in the steel. The carbon content of common steels: mild steel is $0.4 \%$ carbon, medium carbon steel approximately $0.8 \%$ carbon and high carbon steel approximately $1.2 \%$ carbon. Heat treatment is the heating and cooling of metals to change their physical and mechanical properties, without changing its shape. Heat treatment could be said to be a method for strengthening materials, but could also be used to alter some mechanical properties such as improving formability, machining, etc. The process of heat treatment involves the use of heating and cooling, usually to extreme temperatures to achieve the wanted result. It is very important manufacturing processes that not only help manufacturing process, but can also improve product, performance and characteristics in many ways.

Hardening involves heating of steel, keeping it at an appropriate temperature until all pearlite is transformed into austenite and then quenching it rapidly in water or oil. The temperature at which austentizing rapidly takes place depends upon the carbon content in the steel used. The heating time should be increased ensuring that the core will also be fully transformed into the austenite. The microstructure of a hardened steel part is ferrite, martensite or cementite.

Tempering involves heating steel that has been quenched and hardened for an adequate period of time so that the metal can be equilibrated. The hardness and strength obtained depend upon the temperature at which tempering is carried out. Higher temperatures will result into high ductility, but lower strength and hardness. Low tempering temperatures will produce low ductility, but high strength and hardness. In practice, appropriate tempering temperatures are selected that will produce the desired level of hardness and strength. This operation is performed on all carbon steels that have been hardened in order to reduce their brittleness, so that they can be used effectively in desired applications.

If steel is heated until it glows red and is quenched in clean water immediately, it becomes very hard but also brittle. This means it is likely to break or snap if put under great pressure. On the other hand, if the red hot steel is allowed to cool slowly, the resulting steel will be easier to cut, shape and file as it will be relatively soft.

\section{RESULTS AND DISCUSSION}

From the survey and observation, only one sickle blade manufacturer is employed for Jariz CANTAS machines, Kilang Tukang Besi Chop Kwong Yuan Loong which located at Bidor Perak. Site visits to the Kilang Tukang Besi Chop Kwong Yuan Loong found that the sickle blade manufacturing is using the traditional blacksmith method guided only by their experience. They do not have any standard operating procedure for the manufacturing of sickle blade.

The material used for Jariz CANTAS sickle blade manufacturing was identified as spring carbon steel (SUP 9) by the manufacturer. A sample of the material was sent to Jabatan Kimia Malaysia in Petaling Jaya for analyzing and identifying the composition. Fig. 2 shows the result of analysis of SEM (Scanning Electron Microscope) and the result of Wavelength Dispersive X-ray Fluorescence (WDXRF). Table I shows the result of the chemical composition of SUP 9.

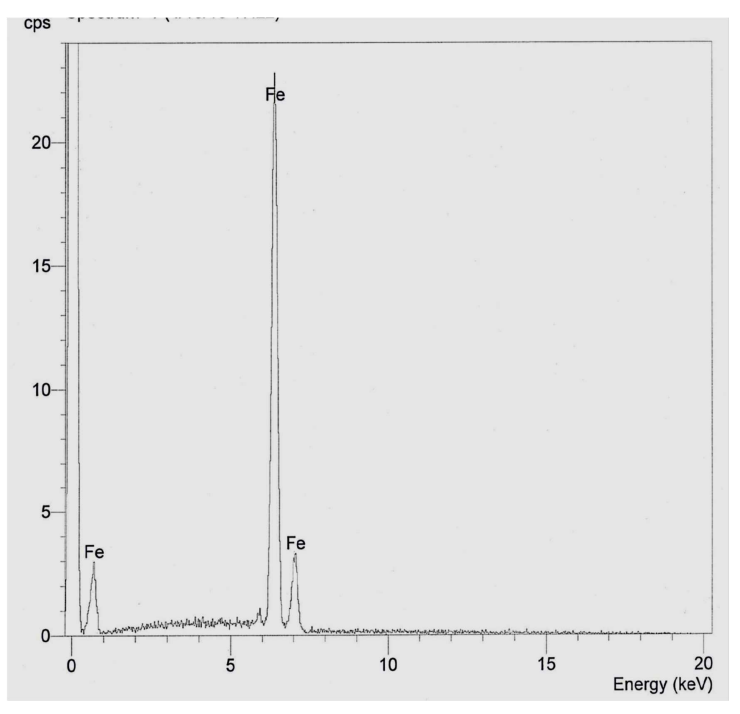

Fig. 2 Results of SEM and WDXRF 
TABLE I

CHEMICAL COMPOSITION OF SUP 9

\begin{tabular}{|c|c|c|c|c|c|}
\hline No & Element & $\begin{array}{c}\text { Weight } \\
(\boldsymbol{\%})\end{array}$ & No & Element & $\begin{array}{c}\text { Weight } \\
(\%)\end{array}$ \\
\hline 1 & $\mathrm{C}$ & 0.271 & 8 & $\mathrm{Cu}$ & 0.197 \\
\hline 2 & $\mathrm{Si}$ & 0.265 & 9 & $\mathrm{Co}$ & 0.025 \\
\hline 3 & $\mathrm{Mn}$ & 0.762 & 10 & $\mathrm{Nb}$ & 0.003 \\
\hline 4 & $\mathrm{P}$ & 0.012 & 11 & $\mathrm{~V}$ & 0.004 \\
\hline 5 & $\mathrm{Ni}$ & 0.213 & 12 & $\mathrm{Ti}$ & 0.001 \\
\hline 6 & $\mathrm{Cr}$ & 0.867 & 13 & $\mathrm{Fe}$ & 97.167 \\
\hline 7 & $\mathrm{Mo}$ & 0.004 & & & \\
\hline
\end{tabular}

Forty-eight specimens were used for hardening and tempering process. The specimens were soaked for 20 minutes [8] at that selected temperature (Table II) in the furnace and quenched in oil for 40 minutes according industrial practical [9]. After hardening, surface hardness was measured and after that the specimens was tempered at selected temperature (Table III). At each tempering temperature sample were soaked for 3 hours [8]. After tempering, surface hardness was measured. Table IV showed the hardness after hardening and tempering.

TABLE III

INDUSTRIAL GUIDELINE FOR HARDENING AND TEMPERING TEMPERATURE

\begin{tabular}{|c|c|c|c|c|c|}
\hline \multirow{2}{*}{$\begin{array}{c}\text { Type of } \\
\text { Steel }\end{array}$} & \multicolumn{2}{|c|}{ Hardening } & \multicolumn{3}{c|}{ Tempering } \\
\cline { 2 - 6 } & $\begin{array}{c}\text { Temperature }\left({ }^{\circ} \mathbf{C}\right) \\
\text { SUP 3 }\end{array}$ & $\begin{array}{c}\text { Hardness (HRC) } \\
\text { oil quenched }\end{array}$ & $\begin{array}{c}\text { Temperature }\left({ }^{\circ} \mathrm{C}\right) \\
\text { Temperature }\left({ }^{\circ} \mathbf{C}\right)\end{array}$ & Hardness (HRC) \\
\hline SUP 6 & $\begin{array}{c}830 \sim 860 \\
\text { oil quenched }\end{array}$ & $\begin{array}{c}830 \sim 860 \\
\text { oil quenched }\end{array}$ & $\begin{array}{c}450 \sim 500 \\
\text { air cooled }\end{array}$ & $36 \mathrm{~min}$ \\
\hline SUP 7 & $\begin{array}{c}830 \sim 860 \\
\text { oil quenched }\end{array}$ & $54 \mathrm{~min}$ & $\begin{array}{c}830 \sim 860 \\
\text { oil quenched }\end{array}$ & $\begin{array}{c}480 \sim 530 \\
\text { air cooled }\end{array}$ & $39 \mathrm{~min}$ \\
\hline SUP 9 & $\begin{array}{c}830 \sim 860 \\
\text { oil quenched }\end{array}$ & $\begin{array}{c}830 \sim 860 \\
\text { oil quenched }\end{array}$ & $\begin{array}{c}490 \sim 540 \\
\text { air cooled }\end{array}$ & $39 \mathrm{~min}$ \\
\hline SUP 10 & $\begin{array}{c}840 \sim 870 \\
\text { oil quenched }\end{array}$ & $\begin{array}{c}830 \sim 860 \\
\text { oil quenched }\end{array}$ & $\begin{array}{c}460 \sim 510 \\
\text { air cooled }\end{array}$ & $39 \mathrm{~min}$ \\
\hline
\end{tabular}

TABLE IIIII

NO OF SAMPLE AND THE HARDENING AND TEMPERING TEMPERATURE

\begin{tabular}{|c|c|c|c|}
\hline No & No of Sample & Hardening Temperature & Tempering Temperature \\
\hline 1 & 3 & 830 & 460 \\
\hline 2 & 3 & 830 & 480 \\
\hline 3 & 3 & 830 & 500 \\
\hline 4 & 3 & 830 & 520 \\
\hline 5 & 3 & 840 & 460 \\
\hline 6 & 3 & 840 & 480 \\
\hline 7 & 3 & 840 & 500 \\
\hline 8 & 3 & 840 & 520 \\
\hline 9 & 3 & 850 & 460 \\
\hline 10 & 3 & 850 & 480 \\
\hline 11 & 3 & 850 & 500 \\
\hline 12 & 3 & 850 & 520 \\
\hline 13 & 3 & 860 & 460 \\
\hline 14 & 3 & 860 & 480 \\
\hline 15 & 3 & 860 & 500 \\
\hline 16 & 3 & 860 & 520 \\
\hline
\end{tabular}

TABLE IVV

THE VALUE OF HARDNESS

\begin{tabular}{|c|c|c|c|c|c|}
\hline $\begin{array}{c}\text { Sample } \\
\text { No. }\end{array}$ & $\begin{array}{c}\text { Quantity in } \\
\text { the Sample }\end{array}$ & $\begin{array}{c}\text { Hardening } \\
\text { Temperature }\end{array}$ & $\begin{array}{c}\text { Average Hardness } \\
\text { Value }\end{array}$ & $\begin{array}{c}\text { Tempering } \\
\text { Temperature }\end{array}$ & $\begin{array}{c}\text { Average Hardness } \\
\text { Value }\end{array}$ \\
\hline 1 & 3 & 830 & 56.25 & 460 & 45.10 \\
\hline 2 & 3 & 830 & 55.73 & 480 & 49.10 \\
\hline 3 & 3 & 830 & 54.79 & 500 & 51.70 \\
\hline 4 & 3 & 830 & 58.55 & 520 & 53.50 \\
\hline Hardness average & 830 & 56.33 & \multicolumn{3}{|l}{} \\
\hline 5 & 3 & 840 & 63.32 & 460 & 48.1 \\
\hline 6 & 3 & 840 & 62.93 & 480 & 50.70 \\
\hline 7 & 3 & 840 & 65.47 & 500 & 53.90 \\
\hline 8 & 3 & 840 & 50.16 & 520 & 55.60 \\
\hline
\end{tabular}




\begin{tabular}{|c|c|c|c|c|c|}
\hline Hardness average & 840 & 60.47 & \multicolumn{3}{|l|}{} \\
\hline 9 & 3 & 850 & 65.72 & 460 & 53.70 \\
\hline 10 & 3 & 850 & 62.32 & 480 & 55.20 \\
\hline 11 & 3 & 850 & 66.25 & 500 & 57.90 \\
\hline 12 & 3 & 850 & 65.51 & 520 & 58.10 \\
\hline Hardness average & 850 & 64.40 & & & 57.00 \\
\hline 13 & 3 & 860 & 70.35 & 460 & 59.90 \\
\hline 14 & 3 & 860 & 71.21 & 480 & 60.05 \\
\hline 15 & 3 & 860 & 68.85 & 500 & 620 \\
\hline 16 & 3 & 860 & 67.19 & 5 & \\
\hline Hardness average & 860 & 69.40 & \multicolumn{5}{|l}{} \\
\hline
\end{tabular}

Induction hardening is a form of heat treatment in which a metal part is heated by induction heating and then quenched. The quenched metal undergoes a martensitic transformation, increasing the hardness and brittleness of the part. Induction hardening is used to selectively harden areas of a part or assembly without affecting the properties of the part as a whole. Fig. 3 shows the part of the sickle blade that need to do the induction process.

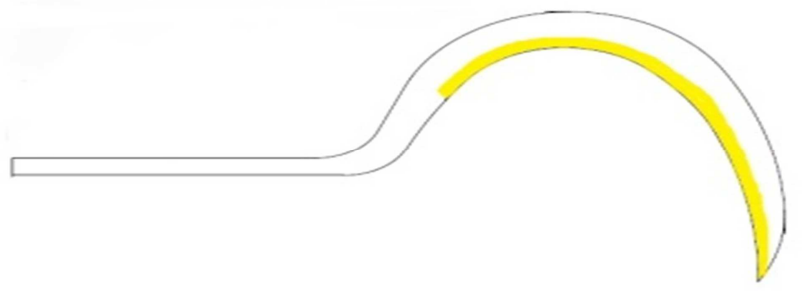

Fig. 3 The area that need to be in the induction process

From the test done, the optimum temperature of SUP 9 material is $850^{\circ} \mathrm{C}$ for hardening and $480^{\circ} \mathrm{C}$ for tempering (Table IV). These values were chosen for the induction hardening process, because the final hardness after tempering according to the DIN standard [10]-[13] should be around $55 \mathrm{HRC}$. From the study, it was found out that the induction process is difficult to perform due to the fact that part of the sickle blade i.e. the sharpened ends only needs to be hardened. While the other part of sickle blade should not be hardened so as to maintain its elasticity. The facilities to perform this induction hardening were limited. After sourcing even to SIRIM Kuala Lumpur to discuss about this study and to obtain their services, we were informed that SIRIM Kuala Lumpur does not offer the induction hardening process. We were told to go to SIRIM at Rasa. But unfortunately, when we went to SIRIM Rasa, we were informed that SIRIM Rasa also do not have induction services.

We also surveyed several heat treatment companies around Selangor and Kuala Lumpur, amongst which are Oriental Heat Treatment (M) Sdn Bhd, Heat Ma Heat Treatment Sdn Bhd and Belton-Oriental Heat Treatment Sdn Bhd. Most of these companies do not provide the induction hardening process in low quantity due to the cost of the induction process. Only one company agreed to provide us the induction hardening services, i.e. Fa Heat Heat Treatment Sdn. Bhd. in Petaling Jaya.

\section{CONCLUSION}

A proposed Standard Operating Procedure (SOP) in producing sickle blades for Jariz Technologies Sdn Bhd is as Fig. 4.

\section{Choose material-SUP 9 (only available in flat strips form)}

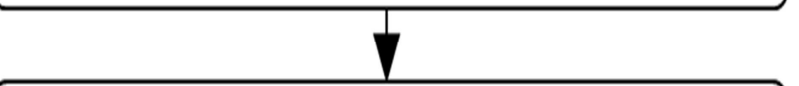

Cut the flat strip to 29 inch long using hydraulic press cutting machine

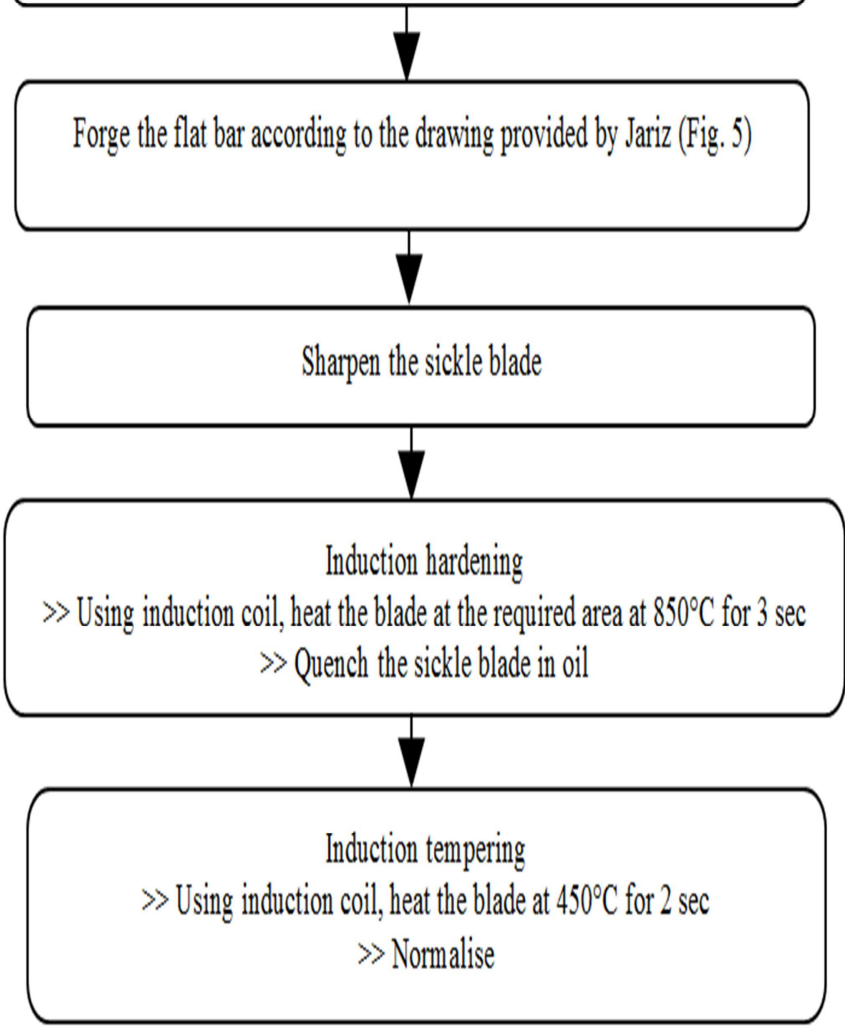

Fig. 4 Standard operating procedure (SOP) 


\section{NOTES:}

\section{HARDENING MUST BE DONE AS THE FINAL PROCESS, AFTER SHARPENING.}

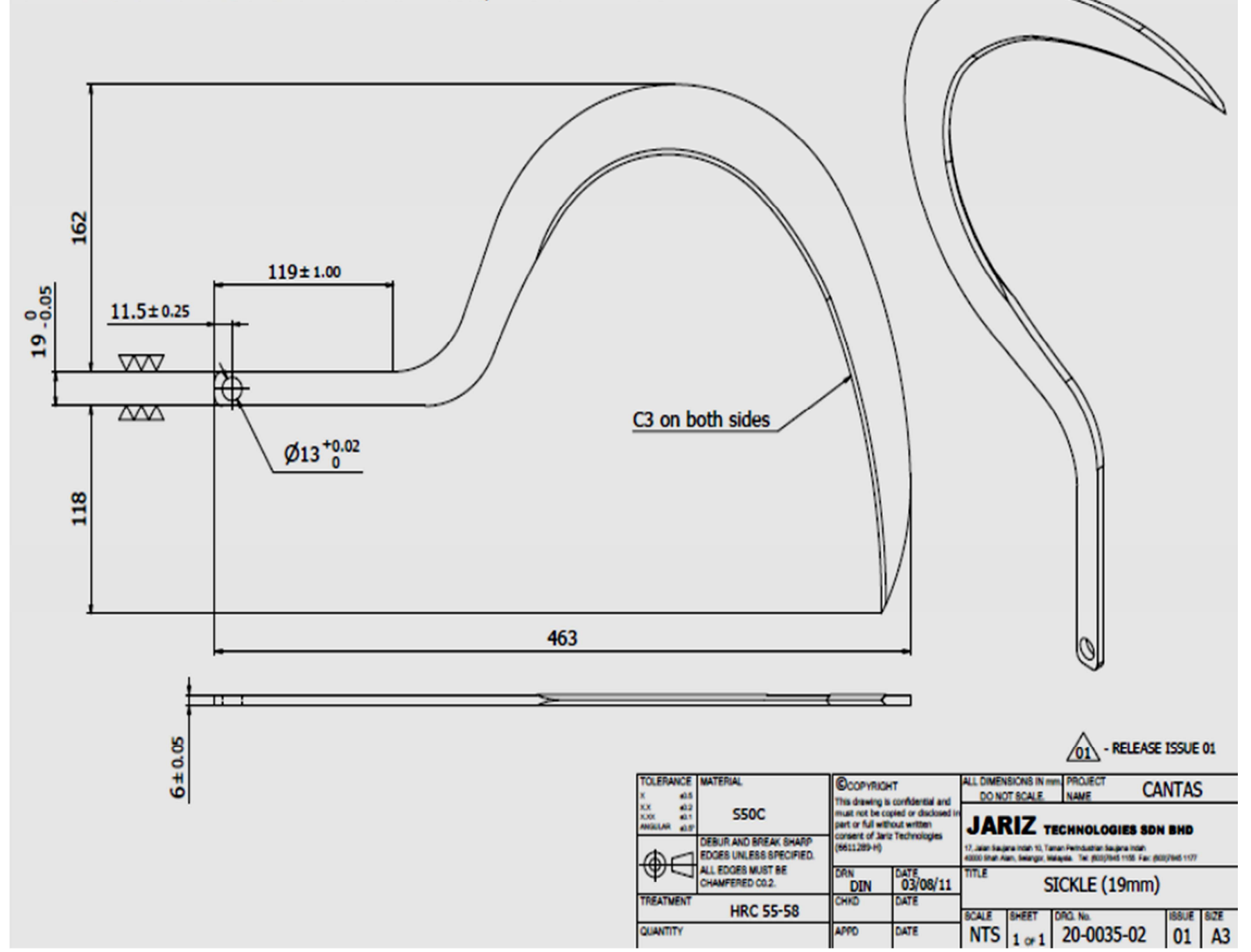

Fig. 5 Drawing of sickle blade

From this study, we found that the optimum temperature for hardening and tempering of SUP 9 was $850^{\circ} \mathrm{C}$ for hardening and $480^{\circ} \mathrm{C}$ for tempering. The final hardness after heat treatment for SUP 9 was around 55HRC.

\section{ACKNOWLEDGMENT}

This study was financially supported by Ministry of Education (MoE) through Public-Private Research Network (PPRN) grant.

\section{REFERENCES}

[1] A. R. Jelani, A. Hitam, A; J. Jamak, M. Noor, Y. Gono and O. Ariffin, "Cantas TM-A tool for the efficient harvesting of oil palm fresh fruit bunches," Journal of Oil Palm Research, vol. 20, pp. 548558, Dec. 2008.

[2] T. Daspattanayak, "Effect of heat treatment on wear properties of plain carbon steel," Degree thesis, National Institute of Technology, Rourkela, India, Nov. 2013.

[3] M. Haftirman, A. R. Syayuthi, M. Anuar and S. Franky, "Effect of tempering temperature on fatigue strength of Thyssen 6582 steel," in Proc. CADME'07, 2007, p. 1-5.
[4] A. Kamp, S. Celotto and D. N. Hanlon, "Effects of tempering on the mechanical properties of high strength dual-phase steels," Journal Materials Science and Engineering: A, vol. 538, pp. 35-41, Mar. 2012.

[5] C. F. Kuang, J. Li, S. G. Zhang, J. Wang, H. F. Liu and A. A. Volinsky, "Effects of quenching and tempering on the microstructure and bake hardening behavior of ferrite and dual phase steels," Journal Materials Science and Engineering: A, vol. 613, pp. 178-183, Sep. 2014.

[6] B. S. Xie,Q. W. Cai, W. Yu, J. M. Cao and Y. F. Yang, "Effect of tempering temperature on resistance to deformation behavior for low carbon bainitic YP960 steels," Journal Materials Science and Engineering: A, vol. 618, pp. 586-595, Nov. 2014.

[7] P. Yan, Z. Liu, H. Bao, Y. Weng and W. Liu, "Effect of tempering temperature on the toughness of $9 \mathrm{Cr}-3 \mathrm{~W}-3 \mathrm{Co}$ martensitic heat resistant steel," Journal Materials and Design, vol. 54, pp. 874-879, Feb. 2014.

[8] M. I. Abro, M. M. Baloch and M. H. Jokhio, "Effect of temperature on the toughness of locally manufactured low alloy steel SUP9 used for manufacturing leaf springs," Mehran University Research Journal of Engineering and Technology, vol. 30, pp. 635-644, Oct. 2011.

[9] Nisshin Steel. (2016) Nisshin Steel quality products. [Online]. Available: http://www.nisshin-steel.co.jp/en/products/pdf/P01-06.pdf. 
[10] H. Lund, "Induction quench hardening of carbon steel axe blades: Improving process parameters for even product quality," Degree thesis, Arcada University of Applied Sciences, Helsinki, Finland, 2011.

[11] M. Spezzapria, M. Forzan and F. Dughiero, "Numerical simulation of solid-solid phase transformations during induction hardening process," IEEE Transactions on Magnetics, vol. 52, pp. 1-4, Mar. 2016.
[12] M. D. Eastwood and K. R. Haapala, "An induction hardening process model to assist sustainability assessment of a steel bevel gear," The International Journal of Advanced Manufacturing Technology, vol. 80, pp. 1113-1125, Mar. 2015.

[13] Y. Wang, Z. Wang, X. P. Qin and K. Gao, "FEM simulation analysis of the effect of air gap on spot induction hardening process," in Proc. ICHSU'15, 2016, p. 332-341. 